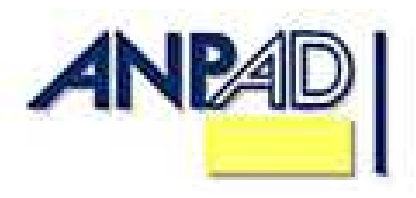

Available online at http://www.anpad.org.br/bar

\title{
Between Two Worlds: an Ethnographic Study of Gay Consumer Culture in Rio de Janeiro
}

Severino Joaquim Nunes Pereira*

E-mail address: bill.pereira4@gmail.com

Universidade Gama Filho

Rio de Janeiro, RJ, Brazil.

Eduardo André Teixeira Ayrosa

E-mail address: eduardo.ayrosa@ @ fgv.br Fundação Getúlio Vargas - EBAPE/ FGV Rio de Janeiro, RJ, Brazil.

* Corresponding author: Severino Joaquim Nunes Pereira

Praia de Botafogo, 124, apto. 502, Botafogo, Rio de Janeiro, RJ, 22250-040. Brazil.

Copyright (C) 2012 Brazilian Administration Review. All rights reserved, including rights for translation. Parts of this work may be quoted without prior knowledge on the condition that the source is identified. 


\begin{abstract}
It is not easy to study socially marginalized groups such as gays, ethnic minorities, and others. This is, however, an extremely relevant topic in the consumer behavior area since the status of members of a modern consumer society is largely denied to stigmatized social groups (Barbosa, 2006). The objective of this work is to shed light on how gay men in Rio de Janeiro use the discourse associated with their possessions to build and maintain the symbolic and hierarchical boundaries between the gay and heterosexual worlds, as well as to investigate the role consumption plays in this boundary setting. An ethnographic observation of a group of gay men in Rio de Janeiro was conducted, along with 20 semi-structured interviews with openly gay men between 2005 and 2008 . The results suggest that: (a) the world culturally built by gays seems to be divided into a gay world and a heterosexual world, where the division between these two worlds not only happens in their minds, but also in their possessions and purchasing decisions; (b) the meaning of gay mens' places of consumption range from profane to sacred along their lives; and (c) in the gay world, the body is seen both as a cultural construction and as an asset.
\end{abstract}

Key words: gay consumption; identity; culture and consumption; stigma. 


\section{Introduction}

Our daily activities follow a certain symbolic scheme that gives them sense and meaning. We feed and dress ourselves, we have fun; that is, we act according to a symbolic scheme that tells us, for example, what to eat, when to eat and how to eat. These schemes are part of the culture, and the assets, services, possessions and experiences can be seen as the basis on which culture is built. Culture can then be understood as the lenses through which all phenomena are seen, understood, interpreted and absorbed (McCraken, 2003). It is the action plan for human activity, which determines the coordinates of social action, specifying the behaviors and objects that arise from them. Culture has to do with the values born from a people's way of living. These values give people an identity frame and guide as to what is good or bad, real or false, life or art (Slater, 2002). Through culture the world is given different meanings, which can be classified into cultural categories and principles.

Culture is not fully hegemonic, though. Certain individuals and groups are able to interpret, transform, resist and change previously established cultural standards. Consumption can be a powerful instrument for establishing dominant social patterns and, at the same time (but seldom through the same ways), resist - and change - these same cultural patterns. In this work, consumption is not treated as something passive in the face of external cultural factors that form culture (Wallendorf \& Arnould, 1991). McCraken (2003) states that marginal groups, like gays and hippies, are able to create tendencies and change previously established cultural standards.

It is not easy to study the consumer behavior area of socially marginalized groups such as gays, ethnic minorities, slum dwellers, drug addicts and others. However, efforts concerning such knowledge are very important in the area of management studies in general, and in consumer behavior in particular. According to Barbosa (2006, p. 8), "the status of members of a modern consumer society is practically denied to certain social groups, like, for example, ethnic minorities". According to the author, most studies of socially excluded groups basically focus on these groups as discriminated, excluded minorities; neutralizing other aspects, like their roles and identities as consumers.

Consumption is also an important component to understand individuals' identities, since individuals communicate and construct themselves using the meanings attributed to their possessions (Belk, 1988). While using their possessions to analyze how consumers are created or how they express their different identities, we began to reflect whether such possessions could be seen as a discourse, since consumption of what we perceive as being ours involves a human action in relation somebody (oneself or somebody else), in a specific interactional context. According to Coelho (2002), objects can identify individuals, groups and cultures and, for that purpose, they become textual aids or units. So, possessions can be considered a discourse that helps individuals in the process of building their identity and communicating with the groups they belong to.

According to Lopes (2003, p. 19), "every discourse comes from somebody with specific identity marks that tell where he fits into social life and uniquely position him, as well as those he speaks to, in his discourse". In other words, when people use their possessions to communicate who they are, they do so not as mere users, but instead, as a discursively qualified persons: a black catholic married heterosexual woman from São Paulo, a white male homosexual from Boston, etc. So, one's possessions communicate who one is, which groups one belongs to, and the roles in and relations with these groups and society as a whole.

This work aims to understand how a specific category of gay men in Rio de Janeiro use the discourse associated with their possessions to build and maintain the symbolic and hierarchical boundaries between the gay and straight worlds, and to investigate the role consumption plays in this boundary setting. Here what we call world is the established symbolic universe these persons live in.

In order to fulfill the objectives of this work, it is necessary to understand how homosexuality was discursively created, the resulting identity related to this category and the relationship between this identity and the development of what is called here the gay market' the social rights of the LGBT 
(lesbian, gay, bisexual and transgender) community and the appearance of gay consumers as an identifiable group. This analysis can provide a better understanding of how the market can be both helpful and harmful to the rights of stigmatized groups like gays - when used in a critical and conscious way.

\section{Theoretical Foundation}

\section{The 'invention' of homosexuality}

Homosexuality and homosexual individuals have been identified - or socially invented - in Brazilian society since the nineteenth century. Until then, emotional and sexual relations between people of the same sex were considered sodomy, shameful behavior anyone could surrender to. As of the second half of the nineteenth century, homosexual practice began to define a special class of individuals, and consequently a new social category, which was marked, stigmatized and known under the name of homosexual, and considered a deviation from the standard. The individuals who fit, or were forced to fit, into this category began to live in secrecy, guided by fear and forced to bear the pains of social segregation (Foucault, 1988; Silva, 2006; Trevisan, 2000).

Over the years, homosexuality was often defined as a pathology or even a perversion. However, it must be noted that a term that does not designate a reality in itself, but rather something that was socially constructed and resulted from a modern moral discourse, is related to the idea of homosexuality. According to Foucault (1988), there was once a project to bring light on all aspects of sex. An apparatus was created to replicate the discourses on sex and thus produce or reproduce truths about it. In the nineteenth century, this project was included in scientific projects, committed to evolutionism and official racism (Gagnon, 2006).

The control of the sex-related mechanisms thus moved from the Church and law to education and science. In practice, there appeared a sciencia sexualis, which produced a truth about sex, testimony being the most valued technique in this production. The overall possibility proposed by Foucault (1988) is that society does not refuse to recognize sex; on the contrary, it puts an entire apparatus into action to produce the true and legitimating discourse with disciplinary objectives.

Based on this discursive construction, heterosexuality was classified as normal and natural, while homosexuality was considered abnormal, a deviation. According to Foucault (1988), the history of sexuality must be understood based on a history of discourses that are entangled in relationships of power and domination. Such division between heterosexuals and homosexuals led the latter to be socially classified and treated as deviants. As a result, they were pushed to the margins of society. This triggered the appearance of interest groups and, consequently, of a homosexual culture with its own sets of behaviors, lifestyles and, foremost, its own feelings, desires, ways of loving, suffering and living life's different experiences (Guimarães, 2004; Kates, 1998, 2002; Nunan, 2003).

In the beginning of the twentieth century, Western culture vigorously repeated the discourse of control and punishment of the several deviations and vices previously reported. However, the history of sexuality passed through great changes in the first four decades of the twentieth century. This was a fraction of the more general turmoil of social changes and questionings. It was within this context that in 1938 Alfred Kinsey conducted his first interviews on sexuality. In 1948 his work "The Sexual Behavior in the Human Male" was published. When publicizing his findings, Kinsey brought sexuality into light in its highest sense, which was revealed openly and straightforwardly in the media of the time (Gagnon, 2006).

Following Kinsey, other researchers in the social sciences contested the labels connected to the homosexual category, which deeply changed between 1950 and 1980 (Gagnon, 2006). In a way, these changes were the consequence of the questioning posed by various social movements - civil rights for 
ethnic minorities, women, gays and civil liberties in general - as well as student rebellions. According to Gagnon (2006), social scientists strongly influenced this process when they questioned the dogmas of psychoanalysis that had provided medical justification for classifying homosexuality as a perversion. Instead, social scientists stated that homosexuality was socially built by culture and history and not by biological factors or early personality disorders.

All this questioning about homosexuality and the social research on homosexual categories contributed to a greater sexual freedom in the 1970s and 80s. In this atmosphere of freedom, the first gay groups, villages and commercial endeavors for gays emerged, giving these groups even greater visibility and freedom. They moved into big urban centers like San Francisco, New York, Toronto, Los Angeles and Rio de Janeiro, and these cities became tourist destinations or places for cultural exchange between these groups (Eribon, 2008; Haslop, Hill, \& Schimidt, 1998; Kates, 1998).

In Brazil, homosexuality historically received similar treatment as it received in the United States and Canada - homosexuality was seen as a disease to be treated or eradicated. In 1890 the Brazilian Penal Code called for punishment of homosexual practices between men, but the references in the text were subtle, using words like "indecent behavior" and "libidinousness," which allowed for different interpretations by jurists (Trevisan, 2000, p. 37).

The way Brazilian society saw homosexuality changed with time, especially after AIDS appeared on the scene, in the 80s; when society once again associated a disease with homosexuality and called AIDS gay cancer. In spite of this, the AIDS epidemic brought to the surface new social organization models for the LGBT community, giving it greater visibility and triggering a broader discussion of issues related to sexual behavior and gender identity in Brazilian society (Pereira, 2004). Despite the deep changes in the way homosexuality is now treated in Brazil, there are still many prejudices found in society. Intolerance, malicious jokes, homophobia, resistance in politics at all levels, and even physical violence are still problems faced by Brazilian homosexuals.

\section{Homosexual identity}

Today, the so-called culturalist perspective of identity has a strong influence on the social theory of identity. According to the culturalist perspective, identity is related to aspects that arise from the individuals' belonging to ethnic, racial, linguistic and/or national groups, that is, from their belonging to one or more groups that share the same attitudes, beliefs and values.

Cultural identity is thus related to a social and historical construct held by a group that shares ideas, values, ways of living and symbols. According to the post-modern perspective adopted by Hall (2004, p. 7); "The old identities, which stabilized the social world for so long, are in decline, giving rise to new identities and fragmenting the modern individual, seen as a unified subject so far".

It is the so-called identity crisis - seen as part of a transition process societies are currently going through. This transition process has shaken reference groups like family and religion, which used to provide stability to an individual's social world. Bauman $(2001,2005)$ corroborates this point of view. He mentions the liquidity of modernity and, as a result, changes in the meanings of institutions and a fluidity of identities. According to Bauman (2001), cultural diversity leads individuals to face multiple identities, which are negotiated, constructed and deconstructed during their lives. These identities are also managed in accordance with the groups people belong to and the situations they face in life.

This view of identities as something fluid and changeable is connected to the identities seen as social - and, therefore, discursive - constructs, since we learn to be who we are in our daily social interactions (Foucault, 1988; Lopes, 2003; P. L. Berger \& Luckman, 2004). This way, identities are not assigned to people in a rigid and static way; rather, they are managed and negotiated by groups and individuals through daily social interactions. 
Therefore, it is not possible to define homosexuality as a single strict and fully outlined identity. Rather, it has to be defined according to the existence of different homosexualities, heterosexualities, manhoods, etc. (Lopes, 2003), which, in this work, means to assume that the basis of cultural identities has changed over the years. Identities are fragmented, dynamic and built in multiple ways in different social discourses, practices and positions.

So, a gay man, for example, is not only a homosexual, but can also be a worker, middle-class, an atheist engineer, etc. Gay men have different identities that often coexist in conflicting or antagonistic ways (e.g. having both gay and father identities). Thus, it cannot be said that an individual has the same identities as other people, but rather that he may have some common identities because he belongs to the same group.

Identity is also related to difference and opposition, since what one is also defines what one is not. It can therefore be said that identity is socially constructed and is related to difference. According to Woodward (2000), the way culture establishes boundaries and distinguishes differences is crucial to understanding identities. She illustrates this aspect as follows: "Identities are forged through the marking of difference. This marking of difference takes place both through symbolic systems of representation and through forms of social exclusion. Identity then is not the opposite of, but it depends on difference" (Woodward, 2000, p. 39).

Identity is usually associated with consumption choices and lifestyles. Concerning lifestyles, Giddens (2002) is a fierce critic of the supeficiality with which this concept is treated when it is associated to consumption, "as suggested by illustrated magazines and advertising" (p. 79). For him, lifestyles can be defined as a group of practices that provide material and narrative forms for autoidentity. In Giddens (2002) conception, defining identity as a form of life describable through consumption practices is not only superficial, but also utterly incomplete: people do not follow lifestyles because they want to, but because they have no other alternative, as it is not a choice. When forging their identities, people somehow try to maintain the social order and end up developing a certain degree of consensus regarding how to classify the social world. According to Woodward (2000), this is the basis of culture, because it is basically through symbols, rituals, and classification that meanings are produced. This concept of culture can be complemented by McCraken (2003), who states that it is possible to understand culture as the ideas and activities through which a society or group forges the meanings and overall sense of the surrounding world. Thus, it is important to understand the concept of culture and its application in social sciences as the way to understand the world of the symbolic meanings of consumption and the relationships both: (a) between the institutions that form the society, and (b) between institutions and individuals.

This construction of cultural meanings and differences, marking binary classificatory systems is, according to Woodward (2000), a means of organizing social life. Social positions are established between insiders and outsiders. The groups classified as outsiders are subject to social control in accordance with the standards of the dominant group that dictates normality - in this case, a hegemonic heterosexual group relative to the gay group.

After addressing the cultural perspective of identity, it is also necessary to discuss consumption as an important producer of meaning in the social world. Consumption can also be seen as a classificatory system to identify and construct identities and differences.

\section{Identity and consumer culture}

Authors like Bauman $(2001,2005)$ and Slater (2002) state that we currently live in a society where social relations are frequently determined by individuals seeking to manage their identities, and that consumption is a powerful dispositive to achieve such purpose. This view is corroborated by Belk (1988), who suggests that individuals' possessions help them define their identities. According to him, individuals frequently define through their possessions the groups and subgroups to which they belong - including the nation and culture of which they are part. 
Bourdieu (2000) also sees the use of consumption as a way to mark differences in the aesthetic choices individuals make. These choices are in fact a form of social distinction. Hence, taste becomes a central element of social judgment. The cultural choices of a group reflect the position the individuals hold in the group and at the same time cause the structure of this group to be reproduced.

It is generally agreed that consumption plays an important role in the construction of individuals' identities. Based on Belk's (1988, p. 139) bold statement, "we are what we have" and what we have are extensions of our identities. Although this sentence may at first seem an apology for the materialism of contemporary society, in fact it conveys what Slater (2002) states to be the logic of a consumer society, where what we possess often overlaps with what we are. It is the primacy of having over being, and the complex confusion between the terms me and mine. Therefore, one of the ways people define themselves is through what they call ours - like family, the groups they belong to, their culture and nation (Belk, 1988). The meaning we give to our possessions can also be related to our group identities. These identities can be associated with a brand community (Muniz \& O'Guinn, 2001), a consumer subculture (Schouten \& McAlexander, 1995), a gender identity (Kates, 2002) or even fans for of a TV series (Kozinets, 2001).

On the other hand, one of the ways of using possessions to define group identity is to differentiate the group's own consumption from that of other groups, or outsiders (Dittmar, 1992). Berger and Heath (2007) argue that in certain domains of social life, consumers frequently make decisions that both make them different from most people and reinforce their similarity to certain groups. Hence, gay consumers use symbolic consumption meanings to make themselves different from heteronormative standards and to communicate or indicate their gay identity to their peers. This dichotomous relationship of differentiation and communication can be seen as a way to confront the stigma of homosexuality.

\section{The market, LGBT movements and gay consumers}

If the market is repeatedly associated with exploitive forces that are harmful to society, and individuals' freedom is sometimes also associated with the emergence of social movements (Kates, 2002; Peñaloza \& Price, 1993), the homosexual movement depends, among other things, on the existence of places for gender-based identities as well as homosexual identity to emerge (Green, 2000). To understand the current context of gay culture in Brazil, it is necessary to analyze how the gay community has grown, and understand its connections with other social movements and with the market.

The gay market - or the dream market, as Peñaloza and Price (1993) calls it - often seen as a recent phenomenon, has in fact grown side by side with gay communities and movements for gay rights. The urbanization process, which brought about a new social structure, is historically connected to the growth of the gay market. This is because aspects of urban development made cities into refuges for homosexuals, in contrast to rural society's extremely conservative mentality in relation to sexuality (Aldrich, 2004; Branchik, 2002).

The fight for the gay rights and the beginning of the organized gay movement in the world date back to the Stonewall riots in Greenwich Village, New York City, that began June 28, 1969, when the patrons of a gay bar, The Stonewall Inn, rioted for days during a raid by the police vice squad (Branchik, 2002). In spite of the importance of this event, the roots of the movement for gay and lesbian liberation had been planted in Germany 100 years before. In fact, the Stonewall riots were the beginning of a new phase of the movement, which was marked by a political transformation in regard to strategies and agenda as well as ideological content (D'Emilio, 1994; Peñaloza \& Price, 1993; Silva, 2006; Trevisan, 2000).

At the same time that the Stonewall riots happened in America, Brazilians experienced the early days of military dictatorship and an increased political resistance to it. Also, the feminist movement began to gain force and voice around the world. The gay movement seems to have followed the trend to strive for greater rights side-by-side with the feminist movement. In the mid-70s, homosexuals took 
to the streets to protest the loss of rights and murders of homosexuals in the United States. In Brazil, student movements called for amnesty for political prisoners. The so-called alternative press also gained force and rapidly expanded circulation. Following this trend, the first gay-oriented newspaper in Brazil appeared - Lampião de Esquina (Lantern Corner) - whose editorial team included several activists from the national gay movement (Branchik, 2002; Silva, 2006; Trevisan, 2000).

In the 80s, the gay market grew in parallel with the reconfiguration of the gay activist movement in Brazil. A large number of gay-oriented bars, nightclubs and other spaces were opened in big urban centers like São Paulo and Rio de Janeiro. If until then gay consumers found themselves marginalized into dark ghettos, squares and public restrooms, the $80 \mathrm{~s}$, marked by efforts for more political freedom, provided the gay community with greater freedom of discourse and consumption (Trigo, 2008).

The emergence of HIV/AIDS on the international gay scene between 1980 and 1990 brought about the reconfiguration of this scene and a greater concern on the part of the gay community with health issues and assistance to HIV-infected members. In the 90s a new wave of gay-oriented services was born with so-called rave parties, held in different places around cities at different intervals (Gontijo, 2007).

In addition to this effervescence in the gay market, the Internet crossed boundaries and emerged as a new, discreet and safe way to meet people and establish social relationships. Websites began to cater to gays' desires and imaginations. Virtual chat rooms became a meeting point for gays, many of whom were still in the closet and searching for casual, discreet dates. Specific tourist packages for gays also became profitable, as part of the overall trend for greater segmentation in the travel market. All this effervescence of the gay market extends to the present day. The number of gay-oriented establishments has significantly grown, as well as the visibility and perceived economic importance of this community (Facchini, 2005; Trevisan, 2000).

\section{Methodology}

In this work we take a constructionist perspective, in that the meanings of the social world are shaped and modified in accordance with human interaction and are the result of historical and cultural development (Berger \& Luckmann, 2004). From this perspective, in order to understand reality, it is necessary to understand the meanings that constitute this real world. So, the researcher needs to explain the process of construction of meanings and how such meanings fit into the discourses and practices of the actors and groups under investigation (Schau, 1998).

Therefore, to understand the reality of the gay group in the city of Rio de Janeiro, it is necessary to understand the social and cultural organization of the world where its members interact, communicate, and thus produce and change its meanings. Based on this, we chose an ethnographic approach. It is characterized for being both descriptive and interpretative. Descriptive because we describe in detail the phenomenon we set out to analyze. Interpretative because we try to understand the group's process of constructing meaning. As Hopkinson and Hogg (2006, p. 157) state: "The interpretevist is concerned with understanding reality under the perspective of the individuals studied in a specific context, and exploring the meanings with which they construct the world they live in".

One of the most remarkable characteristics of ethnography is the insertion of the researcher in the reality of the researched group so that he or she can study the phenomenon from inside. Another characteristic is the tendency to work with data not previously coded as a closed set of analytical categories. According to DaMatta (1978, p. 35), "the anthropological trip is based on the assumption that the understanding of the meanings of social actions should be based on the perspective of the individuals themselves and not on the researcher's". This means to study the phenomenon under the other's view, e.g., in the case of this study, the view of gays in the city of Rio de Janeiro. 
For this purpose, between 2005 and 2008 one of the authors of this work participated in the dayto-day life of a group of gay men in Rio de Janeiro. Besides observation, he conducted formal and informal interviews and analyzed the gay group's material culture such as magazines and goods. To secure the quality and consistency qualitative research requires, we followed the procedures suggested by Wallendorf and Belk (1989), namely: field notes, triangulation and member check. The field notes were created from the observations made, as described above.

In addition to the ethnographic method, we performed interviews based on a semi-structured script with 20 gay men living in Rio de Janeiro (McCraken, 1988). The interviewed subjects were all openly gay men who regularly attended gay-oriented bars, nightclubs, coffee shops and beaches. To select the participants, we used the snowball sampling technique, where an informant invites one of his friends to take part, who in turn invites a friend, and so on. This technique was used by Kates (1998) and Troiden (1989) in studies of homosexual groups. The names of the respondents and any other information that can identify them have been changed. The information collected in these interviews amounts to 28 hours of conversations, which resulted in about 1.800 pages of transcribed text.

We also employed discourse analysis to interpret, through a hermeneutical process, the informants' speech. This analysis was used by Thompson (1996) to understand how consumers construct and change the meanings of the product world they live in.

Although all research methods have limitations, the insights they provide compensates for their instrumental imperfections. Even so, it is important to list here the possible methodological limitations of this work. The research method selected requires the researcher to have significant interpretative skill to address the phenomena being observed. In fact, the researcher does not go to the field naively, free of theories. So, he will focus on what he considers relevant, which may divert him from something important for the understanding of his subject matter.

\section{Data Analysis and Discussion}

We analyzed the data based on the informants' discourses and our daily field notes. The categories presented emerged spontaneously from the analysis of the field notes and interviews carried out. We explored how the individuals used the different cultural meanings of the product world to construct the symbolic boundaries of gay culture - which we call here the gay world - relative to the hegemonic heterosexual culture. Below we present the major categories identified.

\section{Between two worlds: the gay world and the heterosexual world}

The analysis of the informants' discourses showed that the world culturally created by gays seems to be divided into a gay world and a heterosexual world. What seems to be a simplistic division is in fact a representation of the two symbolic universes gays live in and with which they construct their different identities and manage them in accordance with the context. The division into these two worlds is not present in gays' imagination only; it is also represented by things (products and possessions) like clothes, accessories or settings like beaches, bars, nightclubs, etc. Expressions that evidence such division always emphasize the gay's world as mine when referring to the individual, or ours when referring to the gay community. Mentions of a world apart are common, always juxtaposing the gay and heterosexual worlds. The following passages illustrate such symbolic division: "the gay world is much more colored and beautiful (Ricardo, 25)", "I (laughs) found myself! It's my world! (Antônio, 42)", "our world is invisible (overheard in social conversation, fieldnote, 2005)”. 
This symbolic division is also present in the name of the gay-oriented publication DOM (De Outro Modo = In Another Way), a Brazilian magazine that uses expressions like gay universe or gay world in many of its articles.

For most informants, the gay world is strongly associated with their private life, closest friends (which constitute a new family), homo-affective relationships, and a whole symbolic world built around the gay culture. Nevertheless, it would not be possible to think that the group observed here is culturally detached from the rest of society or the heterosexual world. This way, the heterosexual world is an important element in their discourses, and will be described next.

\section{The heterosexual world}

At first the informants reported a strange feeling of difference and ambiguity, an internal confusion, even fear. Numerous reports showed that for a large number of informants, the discovery of their sexual orientation, of the desire for people of the same sex, dated from their late childhood or early adolescence and was associated with a feeling of inadequacy to a heteronormative reality. This identity confusion between being gay or heterosexual is reflected in the way many informants construct themselves through consumption, as Fábio (32 years old) stated: "It has a lot to do with me because I do not like to look like a gay guy, so I choose more conservative clothes". For him, being conservative means to deny his homosexual identity and thus feel safer. Another informant added: "I had to be very quiet; I had to hide myself, so I dressed and behaved like my brother, acted in a way I wouldn't normally act (Alberto, 36)". Dressing as his brother could be equivalent to being in his same heterosexual world. In some circumstances, it is helpful for this informant to hide his homosexual identity. In other situations, though, it is important for him to separate both worlds, making a clear diference between which kind of objects belong to gay and heterosexual word.

This denial of homosexuality found in our sample has also been noted in other studies, where the informants use strategies to hide and disguise their stigmatized identity (Goffman, 1988). Their consumption practices provide a powerful pack of strategies to manage their social identities. Using Goffman's (1959, p. 23) ideas related to the theatrical management of social identity in everyday life, such practices can be interpreted as part of a "role composition", and have a strong centrality in the "routines" homosexuals perform for selected audiences.

Many factors in the informants' discourses were mentioned as the reason for this confusion: (a) the stigma attached to homosexuality; (b) the discursive construction of gayness as abnormality and deviance; (c) the lack of positive references about homosexuality. These factors are often described by the informants as the strong and anedoccal associations heterosexuals make about the female gay stereotype, which form very strong negative references of how gays should act and consume: "then I would have to dye my hair and wear high platform heels, and I would not accept that" (Leonardo, 43).

The importance of goods to build and manage one's identity becomes particularly important when these goods become foci to the extension of self (Belk 1988). As identity is related to difference (Woodward 2000), normal consumption decisions related to clothing - as can be seen in the above mentioned interview quotation - would be categorized as belonging to the heterosexual world, and conversely, the deviant and negatively stereotyped, related to the gay cultural environment. It would be important, at this point, to remember that the word gays use to refer to heterosexuals in Brazilian Portuguese is careta, the same word that is used to refer to a person who is not under the influence of drugs (sober, clearheaded).

\section{The gay world}

The feeling of denial in the informants' discourses first appeared when they began to feel the need to go beyond, to face this fear and set out to explore this other world - a world that was first constructed in their lives as a marginal world, a world of sins and exclusion. 
The first search for information generally took place in books, encyclopedias and on the Internet; the second and more important was described as going to gay-oriented consumer places like bars, nightclubs, coffee shops, etc. It is important to point out here the fundamental role the product world plays in the deconstruction of the stereotype of abnormality and stigma. The members of the group we studied emphatically stated that these consumer settings are like sacred places for them. So, a simple consumption place becomes a safe place where gay men are free from stigma and oppression, which remains on the other side, in another symbolic world.

Empirically, it has been detected that the status of some objects and places is enhanced through the sacralization process, by which the gay and heterosexual symbolic worlds are divided by the meanings attributed to things and, most important, places (Belk, Wallendorf, \& Sherry, 1989). Such sacralization process will be described next.

\section{From profane to sacred: gay-oriented consumer places}

For many informants, the first visit to a gay-oriented setting - like a bar, nightclub or beach was described in an intense and revealing way, a moment often crucial for the acceptance of their homosexual identity.

Alberto's (36) description of the moment he had to decide whether or not to enter a gay nightclub when he was 27 is quite illustrative:

"I had no experience in the gay world. One day I was returning from a party with my girlfriend when she said: 'Look, that's a gay nightclub, Le Boy'. There it was! She had pressed the alarm button and I kept thinking that, if I went in, there would be no coming back. Later I went back and stood in front of the nightclub four times but did not go in. The day I decided to enter, I was just amazed. What I saw right in front of me was not what I had imagined. It was not promiscuous or ugly. Everything was normal and beautiful".

Alberto's statement clearly shows how going to a gay nightclub was connected to the beginning of acceptance of his homosexual identity. He even used the word "alarm" to show how risky the decision was. In this sense, a gay-oriented consumer place was first seen by many informants as a profane place, a place of sin and temptation. For many informants going to such places meant to accept sin, to show lack of respect for their families and for society as a whole. On several opportunities during the study we observed that it was in such bars and nightclubs that the informants could fully experience what it was like to have a homosexual identity, be able to belong to a group of equals, and be able to express themselves freely.

Alberto was surprised at seeing that the place was not promiscuous or profane. In fact, he only saw gay male couples dancing together, groups of friends and mainly a place where he could be himself:

"Visually the nightclub was completely different from what I had imagined my entire life - it was a normal place. Everything was very exciting. It was 'the difference' that attracted me. It was a place where I was a hundred percent myself, where I could dance the way I wanted, look at whoever I wanted without fear. Then I began to go there every weekend and make friends".

This statement shows how Alberto's stereotype of the gay nightclub was deconstructed after he visited one - it was a normal place. More than normal, it was also different; as opposed to the heterosexual world he knew, it was a place where he could be authentic and free. At least there he would not feel himself socially disqualified and stigmatized. Numerous examples in our field notes describe these two moments - before and after going to a gay bar or nightclub - as an extraordinary experience of consumption, as a moment of strong impact in the informants' lives (Arnould \& Price, 1993).

It is interesting to note that there was a change in the informants' discourse. The gay places formerly described as promiscuous, profane, marginal places underwent a process of change of 
meaning for the gays and became sacred places, associated with their home and friends, a place for couples to meet, as Daniel (25) describes below:

"The nightclub 'The Week' became an extension of my home, an extension of myself, because it is a place where I meet my entire group. I simply love it ... There I meet my brothers [referring to his friends], who are facing problems and who I can talk to only on the phone during the week; on the weekends we meet in the club, hug each other, kiss everyone. It's a place where we can be ourselves".

It is noteworthy how a true designation of meanings to certain services happens in this process of acceptance of homosexuality - just like it happened with the nightclub, whose meaning went from negative to positive, from profane to sacred. The gay nightclub, like the gay beach in Rio de Janeiro, was described by the informants as an extension of their own subjectivity.

"The beach in front of the Farme de Amoedo Street is a gathering spot for everybody. On the gay beach I feel comfortable; I can hold hands with my boyfriend. If the beach is not a gay one you obviously cannot do that. If I go to another beach I may even get beat up, which won't happen on a gay beach" (Fábio, 35).

For Fábio, being on a gay beach or in a gay-oriented consumption place means being in a safe place as well as in a place where he will be able to socialize with people like him. However, while socializing, the informants also reported they underwent an intense process of cultural assimilation and change. The symbolism of goods, services and places associated with the gay world serves as a textual support in this process of assimilation and identity construction.

\section{Assimilation and consumption}

The socialization and cultural assimilation uncovered in this research is a process of acquisition of new meanings, beliefs and even new stereotypes related to the gay world. Consumption performs a primary function in this process. It is almost a way to be followed as well as a textual basis the individual must learn how to read and write (McCraken, 2003). It is almost a rebirth, since some informants reported they were required to learn everything again. This process corresponds to a period of transition, a rite of passage where the individual leaves a pre-established status - the heterosexual identity - to construct his homosexual identity. At this point, informants learn how to speak about the threshold between the gay and heterosexual worlds. Such threshold, then gains meaning and full existence.

This process of assimilation of gay cultural standards was described by the informants as a period of real grief and identity deconstruction, where they went through an actual ritual of symbolic disposal of the possessions connected to their heterosexual identity. The same observation was made by Belk (1988) concerning self-extension. The disposal of these possessions and the incorporation of new belongings are related to this time of social ambiguity gays go through, as they alternate between the gay and straight world.

"When I started my gay life I used to dress more like a heterosexual: plain dress slacks and shirts... Then I began to change my style. I left behind the old clothes and became more stylish; so much so that today, when I am invited to a heterosexual place, I don't know what to wear" (Fábio, 35).

Most informants reported having gone through the same change in their self-concept described by Fábio. While the informants first described themselves with words depicting an image tied to a reality that was not their own, afterward they saw themselves as new individuals, introspectively recognizing themselves and seeing themselves in their peers' eyes. The gay identity only exists when affiliation within the world occurs (Cass, 1984; Haslop et al., 1998). Clearly informants wear clothes not only to show their homosexual identity, but also to create a symbolic boundary between the gay and heterosexual worlds.

Although there was a considerable improvement in the informants' self-image with the acceptance of their homosexual identity, there was also a lot of pressure on them to adapt to the gay group's aesthetic standards, in particular regarding the body. 


\section{The body as a cultural construct in the gay world}

The strong aesthetic pressure put on the individuals when they entered the gay world was recurrently described in the informants' discourses. This aesthetic pressure made many informants engage in a process of reconstruction and manipulation of their own bodies. This is consistent with Giddens (2002, p. 76) conception of body as a way to build a unique and integrated self: the body experience is a way to socially say "this is where I live".

The informants described the body as something they have, something that can and must be manipulated in order to adapt it to the standards of gay culture, as reflected in the following comment:

"I think there's a thing with acceptance. You want to be accepted by everyone there. Everyone was exercising, taking steroids. And everyone would say: 'go ahead, take them.' I'd do it and copy what is good! So I joined the craziness of vanity. I underwent liposuction, abdominal liposuction, joined a gym, started swimming, began to take anabolic steroids and I grew larger, larger, larger" (Ricardo, 25).

As described by Ricardo, we commonly saw in the field the various aesthetic services the informants consume: plastic surgeries, cosmetics and even steroids. This hedonistic body consumption is seen positively by the informants, although it results from pressure from the group for them to fit into the aesthetic standards, as Paulo (36) stated:

"Today I look even better, not only in terms of my body, because... the environment changes you; there's really a cult to the body among gays. My body was horrible [laughing]. I was a mega-fat guy... I mean, today I worship my body, I've built sculpted muscles, I go to the gym regularly. The gay environment itself led me to that. If you're in a place where everyone has a body like this... these are their values... the value of what is beauty. So, you have to fit into that or you'll be excluded. I've already been excluded y heterosexual society. It would be too much to be excluded from gay society as well".

As made clear in the above recollections, when they join the gay world the individuals are forced to transform their own bodies so as not to be excluded. Many of them reported that they began to look for gyms, use cosmetics and buy certain types of clothes after they joined the gay world.

[...] "You can see it in gay nightclubs. The guys are stronger. You think they look cool and say to yourself

'I have to look like them.' So I exercise more frequently because of that too" (Luciano, 32).

There is a clear relationship between the aesthetic consumption of the body and the proper ways of covering this body, which is worshiped in gay culture by how to dress it. During the study we verified that gays are very concerned about buying clothes that reveal the male body shape.

"The clothes for gays are stylish, tighter, they shape your body. Here is the cult of the body, the vanity of keeping in good shape so you can show it off, for you to look attractive [...] because gays like good brands, they like to dress well, they are very vain" (Cristiano, 35).

So, what covers the body, which was built and shaped, must also enhance this shape, which, as many informants joked, begins to have a value: "I don't work out for free" (field note).

The hyper valorization of the body - one of the remarkable features of the Carioca (residents of Rio de Janeiro) identity (Goldenberg \& Ramos, 2007), seems to be reflected in the city's gay culture. However, this aesthetics of hyper valorization of the male body seems to be one of the gay group's internal identification codes as well - using aesthetic consumption standards to distinguish insiders from outsiders (Schouten \& McAlexander, 1996).

So, the symbolic meaning of the products, services, possessions and even of the body serves as a textual basis on which they construct their homosexual identity. Just as the informants sacralize gay places like nightclubs, they begin to sacralize everything that is connected to the gay world, like the network of friends, the group's lifestyles, the products associated with this world. The sacralization of all this gay symbolism seems to be the way the informants found to face the social exclusion and stigma this identity carries. 


\section{Final Considerations}

We could observe throughout the study how difficult it is for the informants to live in these two different worlds. For most of them, the gay world is associated with their private lives, their circle of close friends, their new families, the homoaffective relations, a style and consumption model that makes them different from others, and mainly a symbolic world built around a new identification with gay culture. However, it is impossible to think that the group observed here is culturally apart from the heterosexual world.

The division between these two worlds is not clear and its boundaries have always been a reason for tension and questionings for gays' day-to-day lives. Knowing whether they are allowed to hold their partner's hand, whether their clothes are too gay or too hetero, or assessing the degree of risk of new places are recurrent issues in our field notes. On one side, these questionings result from the experience in a heteronormative society, which requires gays to adapt and negotiate the boundaries between these two worlds in the different situations of their day-to-day lives (which vary in relation to the acceptance of homosexuality), or even from the constant changes currently taking place in big cities in what we would call here gay and heterosexual aesthetics.

The meanings given to objects, services and consumption places may undergo a process where what was profane may eventually become sacred (Belk et al., 1989). Some consumption places may also take consumers to a state of displacement, where they experience a sensation of having transcended their existence and reality. During this transcendental experience, consumers may escape from all social pressure, routine and reality itself by means of this extraordinary consumption (Arnould \& Price, 1993). The objects and places associated with this transcendental experience become sacred and begin to hold special meaning for individuals (Belk et al., 1989).

Thus, gays may engage in a process of sacralization of certain gay consumption places because these places are related to experiences that at a certain point in their lives were seen as extraordinary. Many accounts show that going to a gay bar or nightclub for the first time was something extraordinary. Such a process of sacralization operates by removing the venue from the heterosexual world, or attributing to an originally gender-neutral place a collection of narratives and experiences that transform it in a sort of gay place of worship for the wellbeing and freedom it provides. In a practical marketing point of view, such a process is difficult to conduct strategically since most of the narratives and stories concerning personal experiences belong to the gay groups and culture. Since such places go through a process of sacralization, it is extremely difficult for marketing managers to succeed in attracting gay clients without a full understanding of their group culture. Successful strategies may result in solid and long-lasting relationships with its clients.

There is a strong potential for the use of knowledge about gay culture on segmentation of markets. To believe that the gay market is a segment in itself it to grossly overlook the complex gamut of lifestyles existing among gays. As this study has dedicated to a specific group, it was possible to observe that, by making an effort to differ from heterosexuals, this group also strives to build differences from other gay groups. A suggestion for future research lies in the observation of these identity management strategies between different gay groups.

Issues related to identity and consumption are of utmost importance to the analysis of contemporary gay marketing. After all, most of what has been described in this work is related to identity projects (Arnould \& Thompson 2005), as aspects of individual and collective behavior contribute to a better understand of how gay constitute themselves and their relationships with others (Peñaloza \& Price, 1993). This way, the present work provides valuable information for marketing management of business sectors directly related to conducting such identity projects: fashion, travel, leisure, media, architecture and real estate are among the most important areas of application for this knowledge. 
To manage marketing is much more than to satisfy consumers' wants. Good marketing activates complex networks of institutional relations, and as such, has the potential for deeply activating markets. The knowledge presented in this paper can be useful to trigger organizational relationships which are indirectly connected to gay consumers. For instance, the use of such knowledge by hotel managers can enhance other business areas like transportation, health insurance, food and beverages, not to mention place and city marketing. It is important that not only managers, but also people present in the gay market network, be directly involved, and pay close attention to cultural dispositions of the gay consumer groups.

As mentioned above, for future studies, we suggest that the same relationships that were the focus of analysis in this work be investigated with homosexual groups with different characteristics from those of our informants. Older men, people from lower social classes or lesbians would be interesting study targets. There are many different groups of homosexuals with different characteristics and lifestyles, who probably think - and say - that they live in a different world from the ones depicted in this study.

\section{Received 6 September 2010; received in revised form 27 October 2011.}

\section{Acknowledgments}

The author Severino Joaquim Nunes Pereira would like to thanks the support from Conselho Nacional de Pesquisa Cientifica (CNPq).

\section{References}

Aldrich, R. (2004). Homosexuality and the city: an historical overview. Urban Studies, 41(9), 17191737. doi: $10.1080 / 0042098042000243129$

Arnould, E. J., \& Price, L. (1993). River magic: extraordinary experience and the extended service encounter. Journal of Consumer Research, 20(1), 24-45.

Arnould, E. J., \& Thompson, C. J. (2005). Consumer culture theory (CCT): twenty years of research. Journal of Consumer Research, 31(4), 868-882. doi: 10.1086/426626

Barbosa, L. (2006). O consumo nas ciências sociais. In L. Barbosa \& C. Campell (Orgs.), Cultura, consumo e identidade (pp. 21-46). Rio de Janeiro: Editora da Fundação Getulio Vargas.

Bauman, Z. (2001). Modernidade líquida (P. Azevedo, Trans.). Rio de Janeiro: Jorge Zahar Editora. (Original work published 2000)

Bauman, Z. (2005). Identidade: entrevista a Benedetto Vecchi (C. A. Medeiros, Trans.). Rio de Janeiro: Jorge Zahar Editora. (Original work published 2004)

Belk, R. W. (1988). Possessions and the extended self. Journal of Consumer Research, 15(2), 139168.

Belk, R. W., Wallendorf, M., \& Sherry, J. (1989). The sacred and the profane in consumer behavior: theodicy on the odyssey. Journal of Consumer Research, 16(1), 1-38. doi: 10.1086/209191

Berger, J., \& Heath, C. (2007). Where consumers diverge from others: identity signaling and product domains. Journal of Consumer Research, 34(2), 121-139. doi: $10.1086 / 519142$ 
Berger, P. L., \& Luckman, T. (2004). A construção social da realidade. Petrópolis: Editora Vozes.

Bourdieu, P. (2000). Distinction: a social critique of the judgement of taste. Cambridge: Harvard University Press.

Branchik, B. J. (2002). Out in the market: a history of the gay market segment in the United States. Journal of Macromarketing, 22(1), 86-97. doi: 10.1177/027467022001008

Cass, V. C. (1984). Homosexual identity: a concept in need of definition. Journal of Homosexuality, 9(2-3), 105-126.

Coelho, L. A. L. (2002). Tal objeto tal dono. In L. P. M Lopes \& L. C. Bastos (Orgs.), Identidades: recordes multi e interdisciplinares (pp. 69-81). Campinas: Mercado das Letras.

DaMatta, R. (1978). O ofício do etnólogo. In E. O. Nunes (Org.), A aventura sociológica (pp. 23-35). Rio de Janeiro: Zahar.

D'Emilio, J. (1994). Making trouble: essays on gay history, politics and the university. New York: Routledge.

Dittmar, H. (1992). The social psychology of material possessions: to have is to be. New York: St. Martin's Press.

Eribon, D. (2008). Reflexões sobre a questão gay (P. Abreu, Trans.). Rio de Janeiro: Companhia de Freud. (Original work published 2007)

Facchini, R. (2005). Sopa de letrinhas? Movimento homossexual e produção de identidades coletivas nos anos 1990. Rio de Janeiro: Gramond.

Foucault, M. (1988). História da sexualidade I: a vontade do saber (M. C. Albuquerque \& G. Albuquerque, Trans.). Rio de Janeiro: Edições Graal. (Original work published 1988)

Gagnon, J. H. (2006). Uma interpretação do desejo: ensaios sobre o estudo da sexualidade. Rio de Janeiro: Garamount.

Giddens, A. (2002). Modernidade e identidade. Rio de Janeiro: Jorge Zahar Editora.

Goffman, E. (1959). The presentation of self in everyday life. Nova York: Doubleday.

Goffman, E. (1988). Estigma: notas sobre a manipulação da identidade deteriorada. Rio de Janeiro: LTC.

Goldenberg, M., \& Ramos, M. (2007). A civilização das formas: o corpo como valor. In M. Goldenberg (Org.), Nu e vestido: dez antropologos revelam a cultura do corpo carioca (pp. 1940). Rio de Janeiro: Record.

Gontijo, F. (2007). Carioquice ou carioquidade? Ensaio etnográfico das imagens identitárias cariocas. In M. Goldenberg (Org.), Nu e vestido: dez antropologos revelam a cultura do corpo carioca (pp. 41-78). Rio de Janeiro: Record.

Green, J. N. (2000). Além do carnaval: a homossexualidade masculina no Brasil do século XX. São Paulo: UNESP.

Guimarães, C. D. (2004). O homossexualismo visto por entendidos. Rio de Janeiro: Editora Garamont.

Hall, S. (2004). A identidade cultural na pós-modernidade. Rio de Janeiro: DP\&A. 
Haslop, C., Hill, H., \& Schimidt, R. A. (1998). The gay lifestyle - spaces for a subculture of consumption. Marketing Intelligence \& Planning, 16(5), 318-326. doi: $10.1108 / 02634509810229937$

Hopkinson, G. C., \& Hogg, M. K. (2006). Stories: how they are used and produced in market(ing) research. In R. Belk (Ed.), Handbook of qualitative research methods in marketing (pp. 156174). Cheltencham, UK: Edward Elgar.

Kates, S. M. (1998). Twenty million new customers! Understanding gay men's consumer behavior. New York: Harrigton Park Press.

Kates, S. M. (2002). The protean quality of subcultural consumption: an ethnographic account of gay consumers. Journal of Consumer Research, 29(3), 383-399. doi: 10.1086/344427

Kozinets, R. V. (2001). Utopian enterprise: articulating the meanings of star trek's culture of consumption. Journal of Consumer Research, 28(1), 67-88. doi: 10.1086/321948

Lopes, L. P. M. da (Org.). (2003). Discurso de identidades: discurso como espaço de construção de gênero, sexualidade, raça, idade e profissão na escola e na família. Campinas: Mercado das Letras.

McCraken, G. (1988). The long interview. Canada: Sage Publications.

McCraken, G. (2003). Cultura e consumo: novas abordagens ao caráter simbólico dos bens e das atividades de consumo. Rio de Janeiro: MAUAD.

Muniz, A., Jr., \& O'Guinn, T. C. (2001). Brand community. Journal of Consumer Research, 27(4), 412-433. doi: $10.1086 / 319618$

Nunan, A. (2003). Homossexualidade: do preconceito aos padrões de consumo. Rio de Janeiro: Caravansarai.

Peñaloza, L., \& Price, L. (1993). Consumer resistance: a conceptual framework. In L. McAlister \& M. L. Rothschild (Eds.), Advanced in consumer research (pp. 123-128). Colorado: Association for Consumer Research.

Pereira, C. A. M. (2004). O impacto da AIDS, a afirmação da "cultura gay" e a emergência do debate em torno do "masculino" - fim da homossexualidade? In L. F. Rios, V. Almeida, R. Parker, C. Pimenta, V. Terto Jr. (Orgs.), Homossexualidade: produção cultural, cidadania e saúde (pp. 5262). Rio de Janeiro: ABIA.

Schau, H. J. (1998). Discourse of possessions: the metatheory of Russell Belk. Advances Consumer Research, 25(3), 37-44.

Schouten, J. W., \& McAlexander, J. H. (1995). Subcultures of consumption: an ethnographic of the new bikers. Journal of Consumer Research, 22(1), 43-61.

Silva, A. S. (2006). Marchando pelo arco-íris da política: a parada orgulho LGBT na construção da consciência coletiva dos movimentos LGBT no Brasil, Espanha e Portugal ( $\mathrm{PhD}$ thesis). Pontifícia Universidade Católica de São Paulo, São Paulo, SP, Brazil.

Slater, D. (2002). Cultura do consumo \& modernidade (D. A. Azevedo, Trans.). São Paulo: Nobel. (Original work published 2000)

Thompson, C. (1996). Caring consumers: gendered consumption meanings and the juggling lifestyle. Journal of Consumer Research, 22(4), 388-407. 
Trevisan, J. S. (2000) Devassos no paraíso: a homossexualidade no Brasil, da colônia à atualidade. (5a. ed.). Rio de Janeiro: Record.

Trigo, L. G. (2008). Turismo GLS. In A. Panosso Neto \& M. G. R. Ansarah (Orgs.), Segmentação do mercado turístico (pp. 24-41). São Paulo: Moderna.

Troiden, R. R. (1989). Self, self-concept, identity, and homosexual identity: constructs in need of definition and differentiation. Journal of Homosexuality, 10(3-4), 97-109. doi: 10.1300/J082v10n03_13

Wallendorf, M., \& Arnould, T. (1991). Market-oriented ethnography: interpretation building and marketing formulation. Journal of Marketing, 31(4), 484-504.

Wallendorf, M., \& Belk, R. W. (1989). Assessing trustworthiness in consumer research. In E. C. Hirschman (Ed.), Interpretative consumer research (pp. 56-60). Provo, UT: Association for Consumer Research.

Woodward, K. (2000). Identidade e diferença: uma introdução teórica e conceitual. In T. T. Silva (Org.), Identidade e diferença: a perspectiva dos estudos culturais (pp. 7-72). Petrópolis: Vozes. 